\title{
KAJIAN EKSPERIMEN DAN PEMODELAN PENGERING DAUN WASABI DALAM PENGERING RAK DENGAN PEMANAS GAS
}

\section{Experimental Studies and Modeling of Wasabi Leaf Drying in a Rack Dryer With Gas Heating}

\author{
Didik Iswadi \\ Jurusan Teknik Kimia Fakultas Teknik Universitas Pamulang \\ Jl Surya Kencana No. 1 Tangerang Selatan, Banten \\ Email : didikiswadi@gmail.com
}

\begin{abstract}
ABSTRAK
Penelitian yang dilakukan ini tentang pemodelan dan eksperimen dengan pengering rak menggunakan pemanas gas memakai produk daun wasabi. Tujuan yang diambil yaitu memperoleh data pengeringan waktu dan suhu. Membuktikan perubahan laju pengeringan terhadap pengaruh waktu dan suhu pengeringan. Mempelajari model lapisan tipis untuk mendapatkan pemodelan kurva pengeringan. Metode penelitian faktor pertama melakukan pengeringan selama 7,5 jam dan faktor kedua menggunakan suhu 60, 80, 100, 120oC. Variabel meliputi kandungan kadar air \% (kg/g). Hasil penelitian ini menghasilkan nilai efisiensi energi = meningkat dari 30,9\%-35,9\%, konsumsi energi $=$ dari 9,07 x103-1,91 x $105 \mathrm{kj} / \mathrm{kg}$, moisture content $=$ dari $2,2-85,28 \%$, moisture ratio = dari 0,02-0,98, diffusifitas efektif $=$ dari 2,49 x 10-6-4,11 x 10-6 m2s-1, energi aktivasi = 8,53 kj mol-1. Model Newton suhu 80oC adalah model yang terbaik karena model tersebut memperlihatkan hasil nilai yang sesuai dengan nilai observasi yang tidak terlalu jauh. Pada suhu 80oC memberikan nilai X2 dan RMSE = 0,0230-1,1267, R2 = 0,975.
\end{abstract}

Kata kunci: Daun wasabi, Diffusivitas, Efisiensi, Energi aktivasi, Moisture ratio

\begin{abstract}
This research is about modeling and experiments with rack dryers using gas heaters using wasabi leaf products. The purpose taken is to obtain time and temperature drying data. Proving changes in drying rate to the effect of drying time and temperature. Study the thin layer model to get the drying curve modeling. The first method of research was drying for 7.5 hours and the second factor using temperature 60, 80, 100, 120oC. Variables include the content of water content\% $(\mathrm{kg} / \mathrm{g})$. The results of this study produce energy efficiency values = increased from 30.9\%-35.9\%, energy consumption $=9.07 \times 103-1.91 \times 105 \mathrm{kj} / \mathrm{kg}$, moisture content $=$ from 2.27-85.28\%, moisture ratio $=$ from 0.02-0.98, effective diffusion = from $2.49 \times 10-6-4.11 \times 10-6 \mathrm{~m} 2 \mathrm{~s}-1$, activation energy $=8.53 \mathrm{kj}$ mol-1. The Newton model of $800 \mathrm{C}$ is the best model because the model shows the results of the values that correspond to the observation values that are not too far away. At 80oC the value of X2 and RMSE =0.0230 - 1.1267, R2 = 0.975.
\end{abstract}

Keywords: Activation energy, diffusivity, efficiency, leaf wasabi, moisture ratio

\section{PENDAHULUAN}

Daun Daun wasabi di Indonesia ditemukan diwilayah Batur, Dieng, Wonosobo yang menggunakan lahan seluas lima hektar. Untuk meminimalisir kerugian yang dialami, diperlukan pemeliharaan paska panen yang berkualitas baik. Daun wasabi dikenal dengan bahasa latin (Cruciferae) yaitu tumbuhan berasal dari Jepang yang dalam golongan suku kubiskubisan. Produk rimpang yang namanya 
disebut wasabi, disantap yang disamakan dengan penyedap masakan Jepang. Wasabi mempunyai tangkai, daun dan rizoma yang mempunyai bau sedap juga rasa yang kuat menyengat sampai ke hidung. Daun wasabi pada era sekarang tidak banyak diketahui, adanya daun wasabi tidak banyak. Sebagian besar penduduk tidak mengetahui manfaat dan fungsi daun wasabi.

Di Indonesia tumbuhan wasabi dibudidayakan orang Jepang yang berinvestasi di Indonesia. Daun wasabi merupakan produk yang diekspor ke Jepang. Daun wasabi harus dikeringkan dahulu supaya tidak busuk, rusak dan dapat tahan lama. Pengeringan ini sangat mempengaruhi kualitas produknya. Kandungan kimia yang menyebabkan wasabi mempunyai rasa pedas yaitu adanya isothiocyanat. Beberapa eksperimen memperlihatkan mengenai wasabi yang memiliki bahan kimia alami yang dapat menyembuhkan penyakit kanker. Kandungan kimia tersebut populer dengan nama isothiocyanate (8-methyl thiooctyl isothiocyanate, 7 methyl thioheptyl isothiocyanate dan 6 methyl thiohexyl isothio cyanate), senyawa tersebut memiliki sifat anti mikroba. Daun wasabi dimanfaatkan sebagai perasa untuk berbagai produk makanan ringan hingga es krim. Wasabi juga dapat dimanfaatkan sebagai bahan pewarna makanan. Wasabi teruji secara nyata dapat menyembuhkan kanker payudara, kanker paru-paru, leukemia dan penyakit kanker lambung [1]. Pengeringan daun wasabi dengan metode pengeringan daun teh hampir sama. Metode produksi serbuk teh hijau yaitu memanaskan daun teh dengan air suhu $100^{\circ} \mathrm{C}$ selama 15 menit, Mengeringkan daun teh dengan oven vakum suhu $70 \mathrm{oC}$ selama 10 menit, menggiling daun teh dengan blender sampai ukuran $1 \mathrm{~mm}$, memanaskan daun teh dengan air suhu $80^{\circ} \mathrm{C}$ selama selama 30 menit, menyaring daun teh dengan kain, mensentrifugasi selama 10 menit dan menyaring daun teh dengan kertas whatman, memekatkan teh dengan evaporator sampai $20 \%$ suhu $60^{\circ} \mathrm{C}$, serbuk teh sudah jadi [2]. Selama ini sudah dilakukan mengenai pengeringan daun wasabi. Pengeringan ini tidak memakai suhu rendah dan suhu tinggi. Pengeringan yang dilakukan hanya pada suhu $100^{\circ} \mathrm{C}$ dengan lama pengeringan 4 jam.

Penelitian pengeringan daun wasabi yang dilakukan ini menggunakan suhu yang berbeda dan lama pengeringan yang berbeda pula dengan menggunakan alat pengering rak dengan pemanas gas LPG. Penelitian ini tidak hanya memakai suhu 100oC, tetapi memakai suhu rendah dan suhu tinggi serta waktu pengeringan yang lebih panjang pada pengeringan yang telah dilakukan. Pengeringan yang dilakukan memakai suhu pemanasan 60, 80, 100, $120^{\circ} \mathrm{C}$ dan lama pengeringan selama 7,5 jam untuk kualitas daun wasabi. Penelitian ini akan menghasilkan nilai efisiensi energi, kosumsi energi, moisture content, moisture ratio, diffusifitas efektif, energi aktivasi pada daun wasabi. Pengeringan yang dilaksanakan ini sama dengan penelitian experimentation of assam black tea (Camellia sinensis) and drying modelling with produser fuel as a gas.

\section{BAHAN DAN METODE}

Persiapan Persiapan dengan melakukan pencucian daun wasabi pertama dengan menggunakan air, kedua menggunakan air klorin 200 ppm, ketiga menggunakan air garam 2\%, keempat menggunakan air klorin 1000 ppm dengan merendam selama 10 menit. Penirisan daun wasabi ke satu menggunakan basket 
berlubang sampai kurang lebih 5 menit berada pada lokasi yang terbuka, penirisan ke dua memakai box mesin pengering sampai 15 menit. Melaksanakan pemanasan memakai mesin pengering selama 7,5 jam menggunakan suhu 60,80 , $100,120^{\circ} \mathrm{C}$. Dari suhu tersebut pelaksanaan proses pengeringan selama 7,5 jam. Masing-masing suhu pada proses pengeringan menggunakan sampel sebesar 25 gram setiap 30 menit.

Variabel yang dipakai dalam penelitian ini antara lain variabel perlakuan (independen) adalah pemakaian suhu dan lama pengeringan. Variabel dependen antara lain jumlah kadar air \% (kg/g) pada daun wasabi. Eksperimen ini menggunakan 2 faktor antara lain Faktor A (lama pengeringan) adalah memperlakukan pengeringan sampai 7,5 jam pada setiap suhu. Faktor B adalah pengeringan pada suhu $60,80,100,120^{\circ} \mathrm{C}$ ).

\section{HASIL DAN PEMBAHASAN}

Pengeringan adalah cara berpindahnya air mulai dari dalam bahan dengan cara evaporasi dengan memakai kekuatan panas. Sejak pengeringan berjalan tenaga panas ditransfer mulai dari udara sekitar ke luaran bahan, sampai terjadi kenaikan suhu dan mendapatkan uap air yang berada di dalam bahan berjalan dengan kontinyu yang dialirkan keluar dari mesin pengering

Arus udara panas adalah udara kerja untuk sistem pengeringan. Bagian aliran udara yang menghalangi cara pengeringan yaitu kelembaban relatif, tekanan, temperatur dan kecepatan [3]. Pengeringan biji-bijian dapat disamakan sebagai keadaan adiabatik yang mana sejak proses tersebut berjalan, suhu bola basah dan entalpi udara pengering permanen, sedangkan temperatur bola kering susut yang diikuti dengan kenaikan tekanan parsial uap air, suhu pengembunan udara pengering, kelembaban nisbi, dan kelembaban mutlak [4].

Proses pengeringan tergantung oleh sistem pengeringan yang dipakai, sifat internal bahan dan keadaan udara pengering. Kinetika pengeringan diatur oleh tingginya konstanta pengeringan dalam model pengeringan lapis tipis atau sistem yang dipengaruhi dari kadar air, ketebalan bahan, struktur mikro pori-pori bahan, keadaan udara pengering, difusivitas air di dalam bahan dan arus alir udara pengering [5]. Waktu laju pengeringan menurun meliputi dua cara yaitu perpindahan uap air dari permukaan ke udara sekeliling dan perpindahan air dari dalam bahan ke permukaan [6].

Proses pengeringan berlanjut hingga kesetimbangan dipenuhi antara permukaan luar bahan dengan lingkungan sekitarnya, antara permukaan dalam dan permukaan luar bahan. Pada tingkat pertama, diawali dengan waktu pemanasan pendek dengan kecepatan pengeringan maksimum dan tetap. Dalam tingkat pengeringan tersebut, kadar air melampaui kadar air maksimum higroskopis disemua bagian dalam bahan. Dalam hal tersebut, tahap pengeringan bahan tertentu dipengaruhi dari karakteristik bahan antara lain kecepatan udara pengeringan, kelembaban relatif dan suhu bahan [7].

Laju penguapan air dapat dihitung dengan persamaan berikut:

Laju Penguapan Air =

$$
\frac{W t-W_{t+1}}{W a} \times \frac{1}{t_{2-t_{1}}}
$$

Dimana wt merupakan berat awal bahan, $\mathrm{Wt}+1$ merupakan berat bahan pada 
waktu (t, jam) dan Wa merupakan berat bahan saat konstan serta $t_{1}$ dan $t_{2}$ merupakan perubahan waktu setiap jam. Laju penguapan air adalah banyaknya air yang diuapkan setiap satuan waktu atau penurunan kadar air bahan dalam satuan waktu.

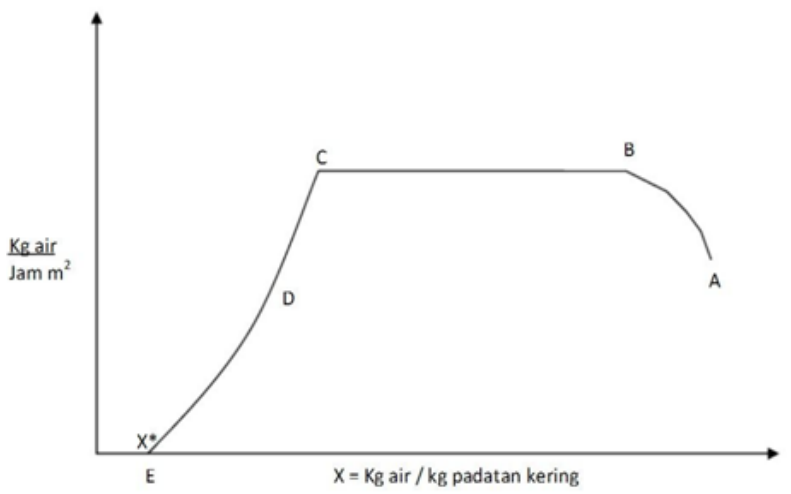

Gambar 1. Kurva hubungan kadar air padatan dengan laju pengeringan

Dalam gambar satu, pada awal proses biasanya suhu padatan lebih sedikit dibandingkan suhu kesetimbangan, sehingga kecepatan pengeringan akan bertambah dengan bertambahnya suhu bahan. Waktu AB menunjukkan waktu awal proses, yang mana laju pengeringan dari awal bertambah dengan cepat, hal tersebut dapat diperhatikan dengan jelas pada waktu A yang menunjukkan perbedaan kurva yang cukup tinggi. Kecepatan-kecepatan pengeringan mengecil dengan sedikit demi sedikit, Sama halnya yang diperlihatkan waktu A-B. Pada waktu $A B$, terdapat waktu $A$ dan $B$, hal tersebut terjadi karena kecepatan evaporasi air pada permukaan lebih tinggi dari pada laju difusi air yang pada posisi dalam bahan ke permukaan. Sehingga awal-awal pada waktu A akan menunjukkan kecepatan evaporasi meningkat dengan cepat, kemudian mengecil pada waktu B karena air pada permukaan telah hilang diuapkan lalu air yang berdifusi dari dalam bahan ke permukaan belum maksimal terpenuhi. Setelah difusi terpenuhi dengan maksimal maka waktu AB akan beranjak ke waktu BC [8].

Waktu BC adalah kecepatan pengeringan tetap. Pada waktu BC memperlihatkan suatu periode dengan kecepatan pengeringan tetap, yang mana tingginya kecepatan ketidaktepatan naik turun mencoba mempertahankan posisinya, selanjutnya dapat disebut membuat garis lurus horizontal dengan bentuk yang sama. Selanjutnya beranjak ke waktu CD yaitu kecepatan pengeringan berkurang, hal tersebut dialami karena tidak tersebar lagi kandungan cairan pada setiap daerah dalam bahan, lalu beranjak ke waktu DE yaitu waktu kecepatan pengeringan berkurang, pada keadaan tersebut terjadi pengurangan kecepatan secara linier. Hal tersebut akan tetap berjalan hingga mencapai kadar air kesetimbangan $X$ [9].

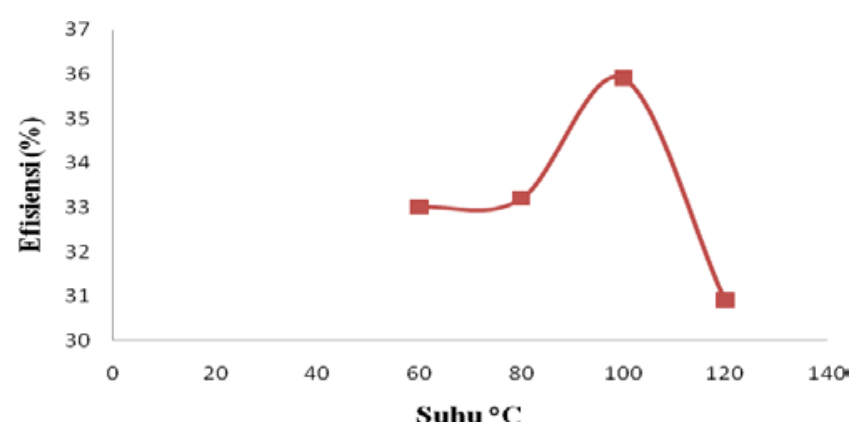

Gambar 2. Pengaruh suhu udara pengering terhadap efisiensi energi

Kadar air dasar kering yaitu massa bahan sesudah melewati pengeringan dalam periode tertentu sampai jumlahnya tetap. Proses pengeringan, air yang terdapat dalam bahan tidak bisa semuanya dievaporasi walaupun seperti itu hasil yang didapatkan dikatakan juga sebagai massa bahan kering [10]. 


\section{Efesiensi energi}

Pada gambar 2, menunjukkan pengaruh peningkatan suhu udara pengering terhadap efisiensi energi. Perhitungan menggunakan persamaan (15) menunjukkan efisiensi energi untuk mengeringkan daun wasabi meningkat dari 30,9 - 35,9\%. Analisisa kinerja penghasilan gas menunjukkan bahwa suhu udara bahan bakar memiliki peran besar untuk alat pembakar. Efisiensi penghasilan gas yang berbeda apinya diperoleh pada suhu 60,80 , 100 dan $120^{\circ} \mathrm{C}$ yang disajikan pada gambar 2. Pada efisiensi energi ini diperoleh maksimum (35\%). Pembakararan untuk efisiensi energi menurun karena tidak sesuai dengan bahan bakar gas dan difusi pembakaran yang mendominasi tempat pembakaran.

Penelitian [11], juga menunjukkan pengaruh yang sama antara peningkatan suhu udara pengering dan efisiensi energi.

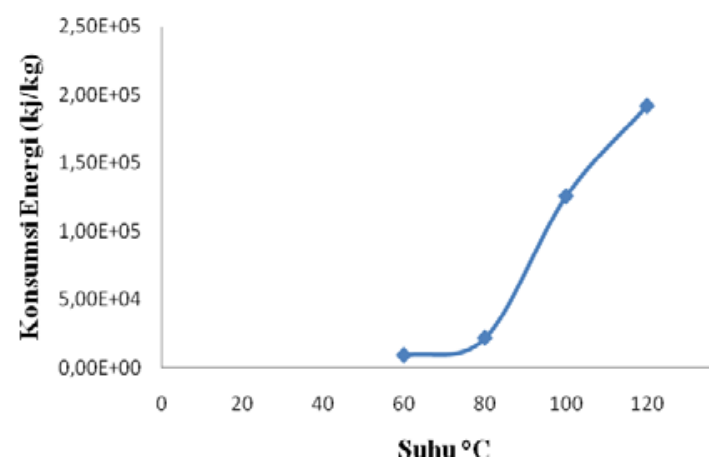

Gambar 3. Pengaruh suhu udara pengering terhadap konsumsi energi

Penelitian [11], juga menunjukkan pengaruh yang sama antara peningkatan suhu udara pengering dan efisiensi energi. Efisiensi yang didapat sebesar 37 - 58\%. Kecenderungan yang sama ditunjukkan oleh semua jenis alat pengering (pengering konvektif, pengering microwave, pengering vakum, pengering surya, dan gabungan alat pengering) bahwa efisiensi energi meningkat dengan meningkatnya suhu udara pengering.

Konsumsi energi pada pengeringan daun wasabi menggunakan pengering rak dengan bahan bakar gas dengan suhu udara pengering $60^{\circ} \mathrm{C}, \quad 80^{\circ} \mathrm{C}, 100^{\circ} \mathrm{C}, 120^{\circ} \mathrm{C}$ ditunjukkan oleh gambar 3 . Analisa energi ini menggunakan data yang diperoleh dari percobaan. Gambar menunjukkan pengaruh suhu terhadap konsumsi energi dimana konsumsi energi meningkat dengan meningkatnya suhu udara pengering pada pengering rak dengan bahan bakar gas. Semakin besar temperatur memperlihatkan bahwa semakin besar kandungan air yang teruapkan. Hal ini disebabkan suhu tinggi menyebabkan transfer panas dan masa yang terjadi juga semakin tinggi sehingga meningkatkan konsumsi energi dalam mengurangi kadar air produk. Dengan menggunakan persamaan (7) diperoleh nilai konsumsi energi dari 9070,23 - 191493,61 $\mathrm{kj} \mathrm{kg}^{-1}$.

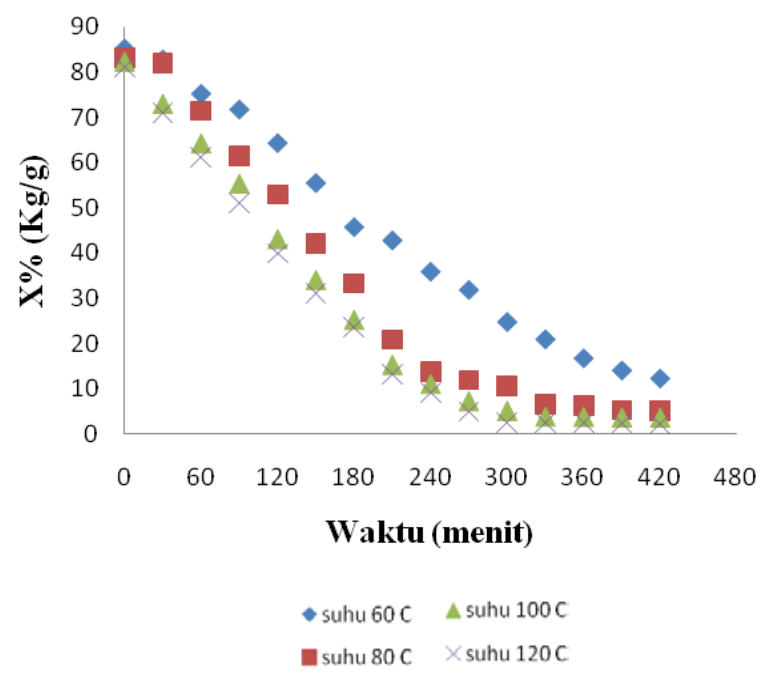

Gambar 4. Penurunan kadar air daun wasabi pada beberapa suhu pengeringan yang berbeda

\section{Moisture Content}

Gambar 4 memperlihatkan kadar air pengeringan daun wasabi pada temperatur $60^{\circ} \mathrm{C}$ memerlukan periode pengeringan 
yang lebih panjang dibandingkan pengeringan daun wasabi pada temperatur 80, 100 dan $120^{\circ} \mathrm{C}$. Pengeringan tersebut diperoleh harga kadar air $=2,27-85,28 \%$. Dari nilai $85 \%$ sampai $10 \%$ hal tersebut terjadi lama pemanasan pendek dengan kecepatan pengeringan maksimum, tahap tersbut terjadi pergeseran air dari dalam bahan ke permukaan dan pergeseran uap air dari permukaan ke udara sekeliling. Selanjutnya pada nilai $10 \%$ sampai 3\% terjadi kecepatan pengeringan tetap, pada waktu tersebut kecepatan yang dalam kondisi turun naik berupaya menyeimbangkan posisinya, maka dapat disebut membuat garis lurus horizontal dengan bentuk yang sama. Selanjutnya pada nilai 3\% kebawah akan menimbulkan keadaan kadar air kritis, pada keadaan tersebut membuat batas antara kecepatan pengeringan tetap dan kecepatan pengeringan mengecil, pada keadaan tersebut akan berjalan hingga mencapai kadar air kesetimbangan. Pengeringan dengan temperatur 80,100 dan $120^{\circ} \mathrm{C}$

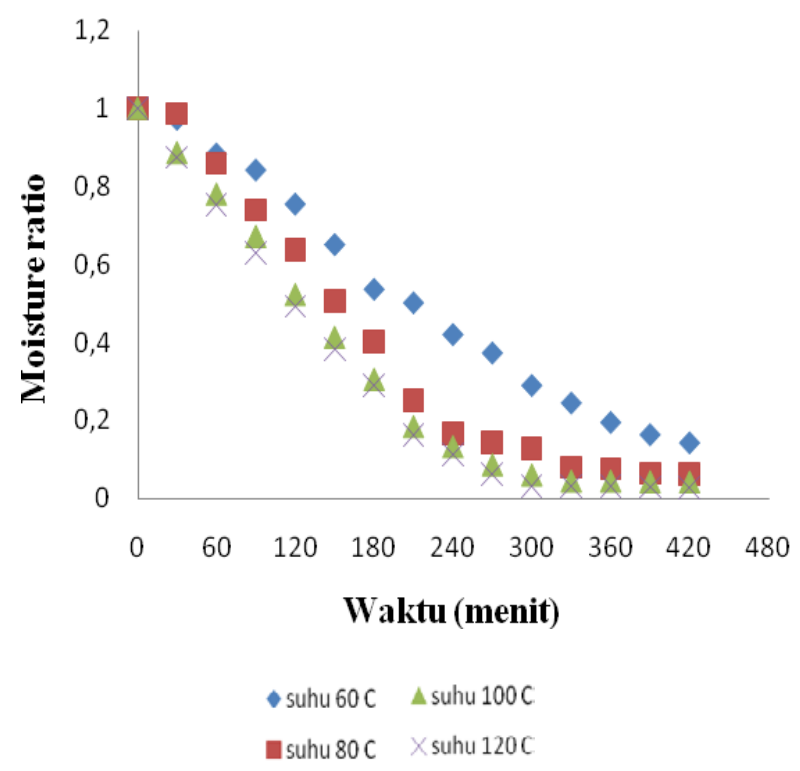

Gambar 5. Grafik MR (Moisture Ratio) selama proses pengeringan daun wasabi adalah pengeringan yang sesuai, karena pada temperatur ini kadar air mempunyai nilai 2-10\%.

\section{Moisture Ratio (Rasio Kelembaban)}

Kecepatan pengurangan nilai MR terhadap lama pengeringan diperlihatkan pada gambar 5. Berkaitan pada gambar 5 di atas, pengurangan nilai Moisture Ratio yang didapat sama dengan pengurangan nilai kadar air bahan dalam proses pengeringan. Dari gambar tersebut, nilai MR dari temperatur 80, 100 dan $120^{\circ} \mathrm{C}$ menunjukkan pengurangan yang sangat besar. Nilai moisture ratio diperoleh $0,02-$ 0,98. Dari temperatur tersebut memperlihatkan pengurangan kadar air yang sangat besar selama pemakaian temperatur yang tinggi dan panjangnya waktu pengeringan. Oleh karena itu tingginya pengurangan MR disebabkan pada panjangnya waktu pengeringan dan tingginya temperatur yang digunakan. Nilai MR tersebut, kemudian dipakai untuk memprediksi model pengeringan.

Pada alat pengering rak daun wasabi dengan pemanas gas ini alur proses pertama aliran udara masuk secara cross dengan membawa energi panas untuk pemindahan air dari dalam bahan melalui penguapan. Pada waktu pengeringan berjalan tenaga panas dipindahkan dari udara sekitar ke permukaan bahan hingga menyebabkan pembesaran temperatur dan menimbulkan uap air yang terdapat di dalam bahan secara terus-menerus di pindahkan keluar dari mesin.

\section{Kesesuaian Model Pengeringan}

Berkaitan hasil analisa desain pengeringan yang telah dibuat yang lalu, maka level kecocokan desain pengeringan yang diperlihatkan pada grafik kaitan desain pengeringan pada 4 tingkatan 
temperatur pengeringan memperlihatkan kesesuaian nilai perkiraan desain terhadap nilai hasil observasi yang semakin tepat. Grafik akan memperlihatkan dari pengeringan yang paling tepat dengan karakteristik pengeringan lapisan tipis, pada percobaab ini yaitu model Newton suhu $80^{\circ} \mathrm{C}$, disebabkan model Newton memberikan nilai $\mathrm{R}^{2}$ mendekati 1 dan $\mathrm{X}^{2}$, RMSE nilainya mendekati 0 dari model lainnya.

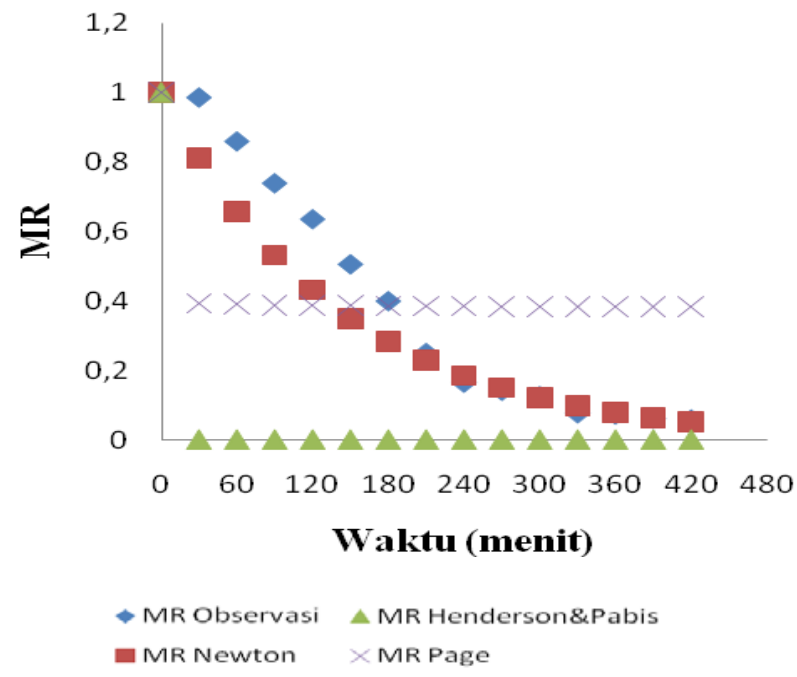

Gambar 6. Grafik nilai model thin layer dengan nilai observasi pada suhu $80^{\circ} \mathrm{C}$

Tabel 1. Diffusivitas Efektif dari Daun Wasabi Pada Berbagai Suhu

\begin{tabular}{cc}
\hline Suhu $\left({ }^{\circ} \mathrm{C}\right)$ & $\begin{array}{l}\text { Diffusivitas } \\
(\mathrm{m} 2 . \mathrm{s}-1)\end{array}$ \\
\hline 60 & $2,49 \mathrm{E}-06$ \\
80 & $3,62 \mathrm{E}-06$ \\
100 & $3,75 \mathrm{E}-06$ \\
120 & $4,11 \mathrm{E}-06$ \\
\hline
\end{tabular}

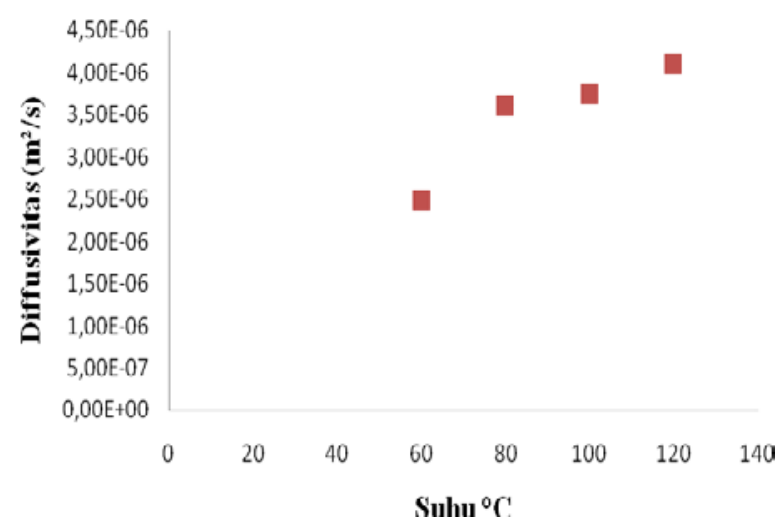

Gambar 7. Grafik nilai deffusivitas terhadap suhu pengeringan

\section{Diffusifitas Efektif}

Diffusivitas efektif pada daun wasabi dengan empat variabel suhu dapat dilihat dengan memploting ln MR dengan waktu (pada gambar 6) dan nilai Diffusivitas efektif adalah kemiringan dari linierisasi kurva diatas, hasil data ditunjukkan pada table 1.

Pada hasil ditunjukkan bahwa, diffusivitas efektif akan bertambah bersamaan dengan bertambahnya temperatur. Penguapan semakin tinggi pada temperatur yang lebih besar, maka dari itu, diffusivitas efektif akan semakin tinggi pula, juga semakin besar pula air yang diuapkan. Oleh karena itu perlu ditingkatkan pemantauan, agar produk yang dibuat tidak mengalami hancur atau gosong karena efek dari temperatur kerja yang terlalu besar.

\section{Energi Aktivasi}

Pada gambar keterkaitan 1/T dengan ln Deff yang dilinierisasi diperoleh kemiringan. Ditinjau dari kinetika diffusi mengikuti persamaan Arrhenius, kemiringan tersebut sebagai nilai $\mathrm{Ea} / \mathrm{R}$, maka dari itu bisa dihitung tenaga aktivasinya sehingga diperoleh nilai 8,53 $\mathrm{Kj} \mathrm{mol}^{-1}$ 


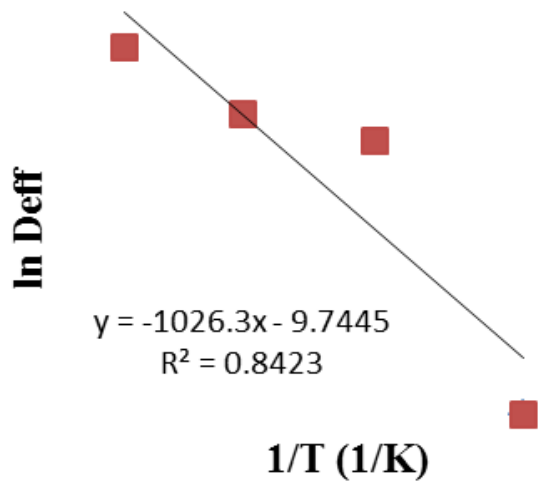

Gambar 8. In Diffusivitas Efektif Sebagai fungsi Dari Suhu

Pengeringan daun wasabi menggunakan waktu dan suhu 60, 80, 100 dan $120^{\circ} \mathrm{C}$ menghasilkan kurva pengeringan untuk moisture content dengan nilai kurva menurun dari 2,27 - 85,28\%, moisture ratio dengan nilai kurva menurun dari 0,02-0,98, diffusivitas efektif dengan nilai kurva meningkat dari $2,49 \times 10^{-6}-$ $4,11 \times 10^{-6} \mathrm{~m}^{2} / \mathrm{s}$. Selama pengeringan pada moisture content dan moisture ratio dengan suhu 80,100 dan $120^{\circ} \mathrm{C}$ laju pengeringan meningkat diamati selama awal 150 menit. Setelah itu, laju pengeringan terus menurun dengan perubahan sangat besar, akibatnya kadar air menyusut mencapai berat konstan yang dimulai pada waktu 240 menit. Berkaitan pada ketiga nilai kesamaan itu, maka model Newton suhu $80^{\circ} \mathrm{C}$ merupakan yang paling sesuai karena model memperlihatkan kesesuaian nilai prediksi model kepada nilai hasil observasi yang tidak beda jauh yang memberikan nilai $\mathrm{R}^{2}$ mendekati 1 dan nilai $\mathrm{X}^{2}$, RMSE mendekati 0 dari model lainnya. Pada suhu $80 \circ \mathrm{C}$ memberikan nilai X2 dan RMSE $=0,0230$ $1,1267, \mathrm{R}^{2}=0,975$.

\section{Saran}

Pengeringan daun wasabi bisa diaplikasikan lebih mendalam lagi. Proses pengeringan daun wasabi dilakukankan dengan hati - hati, sering mengontrol keadaan suhu yang digunakan.

\section{DAFTAR PUSTAKA}

[1] Depree J.A., Howard T.M and Savage G.P. 1999. Flavour and pharmaceutical properties of the volatile sulphur compounds of Wasabi (Wasabia japonica). Food Research International. Vol. 31. No. 5. pp. 329-337.

[2] Vuong, Q.V., Golding, J.B., Nguyen, M.H., and Roach, P.D. 2012. Production of caffeinated and decaffeinated green tea catechin powders from underutilised old tea leaves. Journal of Food Engineering. 110:1 - 8 .

[3] Brooker D. B., Bakker-arkema F.W and Hall C.W. 1981. Drying Cereal Grains. Avi Publishing Company Inc. West Port, Connecticut.

[4] Mahadi. 2007. Model Sistem dan Analisa Pengering Produk Makanan. USU Repository. Universitas Sumatera Utara.

[5] Istadi., Sumardiono Y dan Soetrisnanto D. 2002. Penentuan Konstanta Pengeringan dalam Sistem Pengeringan Lapis Tipis (Thin Layer Dring). Prosiding Seminar Nasional Teknologi Proses Kimia. Hotel Sahid Jaya Jakarta.

[6] Henderson S.M. and Perry R.L. 1976. Agricultural Process Engineering.3rd ed. The AVI Publ. Co., Inc, Wesport. Connecticut, USA.

[7] Sitkei G. 1986. Mechanics of Agricultural Materials. Developments in Agricultural Engineering 8. Elsevier 
Science Publishers. Budapest, [10] Taib S., Said G dan Wiraatmadja V. Hungary.

[8] Lydersen A.L. 1983. Mass Transfer in 1988. Operasi Pengeringan pada Pengolahan Hasil Pertanian. MSP. Engineering Practic, John Willey \& Sons. New Delhi.

[9] Porter H.F., Schurr G.A., Wells D.F and Semrau K.T. 1992. Solids Drying and Gas-Solid Systems.McGraw-Hill, New York.

Jakarta.

[11] Dutta P.P and Baruah D.C. 2014. Drying modelling and experimentation of assam black tea (Camellia sinensis) with producer gas as a fuel. Applied Thermal Engineering. 63495 - 502. 